\title{
Response by sex to statin plus ezetimibe or statin monotherapy: A pooled analysis of 22,231 hyperlipidemic patients
}

\author{
Beth L Abramson ${ }^{1 *}$, Pascale Benlian ${ }^{2}$, Mary E Hanson ${ }^{3}$, Jianxin Lin ${ }^{3}$, Arvind Shah ${ }^{3}$ and Andrew M Tershakovec ${ }^{3}$
}

\begin{abstract}
Background: Despite documented benefits of lipid-lowering treatment in women, a considerable number are undertreated, and fewer achieve treatment targets vs. men.

Methods: Data were combined from 27 double-blind, active or placebo-controlled studies that randomized adult hypercholesterolemic patients to statin or statin+ezetimibe. Consistency of treatment effect among men $(n=11,295)$ and women $(n=10,499)$ was assessed and percent of men and women was calculated to evaluate the between-treatment ability to achieve specified treatment levels between sexes.

Results: Baseline lipids and hs-CRP were generally higher in women vs. men. Between-treatment differences were significant for both sexes (all $p<0.001$ except apolipoprotein $\mathrm{A}-\mathrm{I}$ in men $=0.0389$ ). Men treated with ezetimibe +statin experienced significantly greater changes in LDL-C $(p=0.0066)$, non-HDL-C, total cholesterol, triglycerides, HDL-C, apolipoprotein A-I (all $p<0.0001)$ and apolipoprotein $B(p=0.0055)$ compared with women treated with ezetimibe+statin. The odds of achieving $\mathrm{LDL}-\mathrm{C}<100 \mathrm{mg} / \mathrm{dL}$, apolipoprotein $\mathrm{B}<90 \mathrm{mg} / \mathrm{dL}$ and the dual target [LDL-C $<100 \mathrm{mg} / \mathrm{dL} \&$ apoliprotein $\mathrm{B}<90 \mathrm{mg} / \mathrm{dL}$ ] was significantly greater for women $\mathrm{vs}$. men and the odds of achieving hs-CRP $<1$ and $<2 \mathrm{mg} / \mathrm{L}$ and dual specified levels of [LDL-C $<100 \mathrm{mg} / \mathrm{dL}$ and $\mathrm{hs}-\mathrm{CRP}<2 \mathrm{mg} / \mathrm{L}$ ] were significantly greater for men vs. women. Women reported significantly more gall-bladder-related, gastrointestinalrelated, and allergic reaction or rash-related adverse events (AEs) vs. men (no differences between treatments). Men reported significantly more CK elevations (no differences between treatments) and hepatitis-related AEs vs. women (significantly more with ezetimibe+simvastatin vs. statin).
\end{abstract}

Conclusions: These results suggest that small sex-related differences may exist in response to lipid-lowering treatment and achievement of specified lipid and hs-CRP levels, which may have implications when managing hypercholesterolemia in women.

Keywords: low-density lipoprotein cholesterol, hyperlipidemia, ezetimibe, statin

\section{Background}

The average lifetime risk for cardiovascular disease (CVD) in women is very high, approaching 1 in 2 [1]. Accordingly, the 2011 update to the Guidelines for Cardiovascular Disease Prevention in Women asserts that nearly all women are at risk for CVD and stresses the importance of CVD prevention and appropriate treatment based on appropriate risk assessment [2]. In addition, the new guidelines lowered the threshold defining

\footnotetext{
* Correspondence: abramsonb@smh.ca

${ }^{1}$ St. Michael's Hospital, Toronto, Ontario, Canada

Full list of author information is available at the end of the article
}

high risk to $>10 \% 10$-year risk for CVD. With few exceptions, recommendations for preventive measures for CVD are similar in men and women. For cardiovascular risk reduction, the primary target for men and women is low-density lipoprotein cholesterol (LDL-C) $[2,3]$. Optimal levels of high-density lipoprotein cholesterol (HDL-C), non-HDL-C, and triglycerides have also been recommended for women [2]. In the general population attainment of recommended lipid levels is suboptimal, and fewer women achieve recommended lipid levels compared with men [4]. Even though women are less likely to be recruited in clinical trials $[5,6]$, there is
Ciomed Central

(ㄷ) 2011 Abramson et al; licensee BioMed Central Ltd. This is an Open Access article distributed under the terms of the Creative Commons Attribution License (http://creativecommons.org/licenses/by/2.0), which permits unrestricted use, distribution, and reproduction in any medium, provided the original work is properly cited. 
good evidence showing similar benefits of lipid-lowering treatment in both sexes [2,7]. Despite this, a considerable number of women are undertreated, possibly due to perceived lower risk for CVD in women [2].

Findings from the Women's Health Initiative and the Heart and Estrogen/Progestin Replacement Study underscore the importance of evidence-based practice for CVD prevention in women [8,9]. Elucidation of sexrelated tolerability and efficacy of specific lipid-lowering treatments may help provide perspective for evidencebased decision making, tailor preventive interventions based on individual risk and benefit, and increase the number of patients attaining individual treatment goals. The objectives of this analysis were to assess sex-related tolerability and lipid-altering efficacy and achievement of specified lipid and high-sensitivity $\mathrm{C}$-reactive protein (hs-CRP) levels in men and women treated with statin + ezetimibe or statin monotherapy in a broad, pooled database of greater than 21,000 patients.

\section{Methods}

Data were combined from 27 double-blind, active- or placebo-controlled efficacy studies that randomized adult hypercholesterolemic patients to statin alone or statin plus ezetimibe. Studies were conducted from 1999 to 2008 by Merck Research Laboratories to ensure full access to individual patient data (Table 1). Studies with cross-over design, extension studies, studies still ongoing, outcome or imaging studies, studies in which ezetimibe was used as monotherapy or in combination with other non-statin lipid-lowering drugs (e.g., fenofibrate, niacin), adolescent or pediatric patient studies, and studies focusing on patients with sitosterolemia, homozygous familial hypercholesterolemia, aortic stenosis, or chronic kidney disease were not included in the analyses.

Specific inclusion criteria for the individual studies have been previously published (see citations in Table 1). As guidelines changed over time, there was no single lipid entry criterion that applied to all studies. In general, a patient was considered hypercholesterolemic if LDL-C levels were above guideline-recommended levels according to risk. The range of baseline LDL-C inclusion levels in the studies was $>70 \mathrm{mg} / \mathrm{dL}$ to $<250 \mathrm{mg} / \mathrm{dL}$ (Table 1 ). Ezetimibe add-on treatments included ezetimibe $10 \mathrm{mg}$ added to atorvastatin $10-80 \mathrm{mg}$, ezetimibe $10 \mathrm{mg}$ added to lovastatin $10-40 \mathrm{mg}$, ezetimibe $10 \mathrm{mg}$ added to pravastatin $10-40 \mathrm{mg}$, ezetimibe $10 \mathrm{mg}$ added to simvastatin $10-80 \mathrm{mg}$, and ezetimibe $10 \mathrm{mg}$ added to ongoing statin dose. Statin monotherapy included atorvastatin 10-80 $\mathrm{mg}$, lovastatin $10-40 \mathrm{mg}$, pravastatin $10-40 \mathrm{mg}$, rosuvastatin $10-40 \mathrm{mg}$, and simvastatin $10-80 \mathrm{mg}$.

Drug-naïve patients were randomized to receive double-blind ezetimibe/statin [ezetimibe/simvastatin combination tablet $(10 / 10,10 / 20,10 / 40$ or $10 / 80 \mathrm{mg})$ or ezetimibe $10 \mathrm{mg}$ co-administered with: simvastatin 10 , 20,40 or $80 \mathrm{mg}$; lovastatin 10,20 or $40 \mathrm{mg}$; pravastatin 10,20 or $40 \mathrm{mg}$ or atorvastatin $10,20,40$ or $80 \mathrm{mg}$ ] or statin alone (simvastatin 10, 20, 40 and $80 \mathrm{mg}$; lovastatin 10,20 and $40 \mathrm{mg}$; pravastatin 10, 20 and $40 \mathrm{mg}$; atorvastatin 10, 20, 40 and $80 \mathrm{mg}$ or rosuvastatin 10, 20 or $40 \mathrm{mg}$ ) for up to 12 weeks. In the add-on therapy studies, statin-treated patients were randomized to receive double-blind placebo or ezetimibe $10 \mathrm{mg}$ administered in combination with their ongoing, previously prescribed, open-label statin (simvastatin 20 or $40 \mathrm{mg}$ or atorvastatin 10,20 , or $40 \mathrm{mg}$ ) or doubling the statin dose (to simvastatin 40 or $80 \mathrm{mg}$ or to atorvastatin 20 , 40 , or $80 \mathrm{mg}$ ) for up to 24 weeks. In switch-therapy studies, statin-treated patients were switched from their ongoing, previously prescribed, open-label statin (simvastatin 20 or $40 \mathrm{mg}$; pravastatin $40 \mathrm{mg}$; fluvastatin 80 mg; atorvastatin 10 or $20 \mathrm{mg}$; or rosuvastatin $5 \mathrm{mg}$ ) to receive double-blind ezetimibe/statin (ezetimibe/simvastatin combination tablet $10 / 20$ or $10 / 40 \mathrm{mg}$ ) or statin alone (atorvastatin $20 \mathrm{mg}$ or rosuvastatin $10 \mathrm{mg}$ ) for up to 6 weeks.

\section{Efficacy Measures}

The \% change from baseline to study end in LDL-C, HDL-C, non-HDL-C, total cholesterol, triglycerides, apolipoprotein $\mathrm{B}$, apolipoprotein $\mathrm{A}-\mathrm{I}$; ratios for total cholesterol/HDL-C, LDL-C/HDL-C, apolipoprotein B/ apolipoprotein A-I, non-HDL-C/HDL-C; and hs-CRP were measured. In addition, the $\%$ of patients achieving the single specified targets of LDL-C $<100 \mathrm{mg} / \mathrm{dL}$, nonHDL-C $<130 \mathrm{mg} / \mathrm{dL}$, apolipoprotein $\mathrm{B}<90 \mathrm{mg} / \mathrm{dL}$, and specified levels of hs-CRP $<2 \mathrm{mg} / \mathrm{L}$ and $<1 \mathrm{mg} / \mathrm{L}$ as well as the dual specified levels of LDL-C $<100 \mathrm{mg} / \mathrm{dL}$ \& non-HDL-C $<130 \mathrm{mg} / \mathrm{dL}, \mathrm{LDL}-\mathrm{C}<100 \mathrm{mg} / \mathrm{dL}$ \& apolipoprotein $\mathrm{B}<90 \mathrm{mg} / \mathrm{dL}, \mathrm{LDL}-\mathrm{C}<100 \mathrm{mg} / \mathrm{dL} \&$ hs-CRP $<2 \mathrm{mg} / \mathrm{L}, \mathrm{LDL}-\mathrm{C}<100 \mathrm{mg} / \mathrm{dL} \& \mathrm{hs}-\mathrm{CRP}<1$ $\mathrm{mg} / \mathrm{L}$ were calculated.

\section{Laboratory methods}

Analysis of samples for all clinical laboratory values were performed at a certified central laboratory according to standards specified by the National Heart Lung and Blood Institute and Centers for Disease Control and Prevention. LDL-C levels were calculated using the Friedewald equation or measured directly using the betaquantification method if triglycerides were $>400 \mathrm{mg} / \mathrm{dL}$.

\section{Statistics}

Efficacy was assessed in a modified version of the intentto-treat population, which includes all randomized patients who had baseline values, had taken at least 1 dose of study medication, and had 1 or more post- 
Table 1 Characteristics of studies included in the pooled analyses

\begin{tabular}{|c|c|c|c|c|c|c|c|}
\hline \multirow[t]{2}{*}{$\begin{array}{l}\text { Protocol Number } \\
\text { [citation] }\end{array}$} & \multirow[t]{2}{*}{ Treatment } & \multicolumn{2}{|c|}{$\begin{array}{l}\text { Randomized to } \\
\text { Statin }\end{array}$} & \multicolumn{2}{|c|}{ Randomized to Statin+EZ } & \multicolumn{2}{|c|}{ Inclusion Criteria } \\
\hline & & $\begin{array}{c}\text { Men } \\
(\mathrm{N}=5389)\end{array}$ & $\begin{array}{l}\text { Women } \\
(\mathrm{N}=5142)\end{array}$ & $\begin{array}{c}\text { Men } \\
(\mathrm{N}=6140)\end{array}$ & $\begin{array}{c}\text { Women } \\
(\mathrm{N}=5607)\end{array}$ & Min LDL-C & Max LDL-C \\
\hline $\begin{array}{l}005 \\
{[37]}\end{array}$ & $\begin{array}{c}\text { PBO, EZ } \\
E Z+S 10,20,40,80 \\
S 10,20,40,80\end{array}$ & 172 & 177 & 169 & 184 & $145 \mathrm{mg} / \mathrm{dL}$ & $250 \mathrm{mg} / \mathrm{dL}$ \\
\hline $\begin{array}{l}011 \\
{[38]}\end{array}$ & $\begin{array}{c}\text { PBO, EZ } \\
\text { S } 10,20,40,80 \\
\text { EZ+S } 10,20,40,80\end{array}$ & 110 & 153 & 126 & 148 & $145 \mathrm{mg} / \mathrm{dL}$ & $250 \mathrm{mg} / \mathrm{dL}$ \\
\hline $\begin{array}{l}021 \\
{[15]}\end{array}$ & $\begin{array}{c}S 20+E Z \\
\text { Doubling S to } 40\end{array}$ & 61 & 49 & 62 & 42 & $101 \mathrm{mg} / \mathrm{dL}$ & not specified \\
\hline $\begin{array}{l}\mathbf{0 2 3} \\
{[25]}\end{array}$ & $\begin{array}{c}S 20 \\
E Z+S 10,20,40\end{array}$ & 158 & 95 & 292 & 165 & $130 \mathrm{mg} / \mathrm{dL}$ & not specified \\
\hline $\begin{array}{l}025 \\
{[39]}\end{array}$ & $\begin{array}{c}A 10 \\
E Z+S 10,20\end{array}$ & 131 & 131 & 279 & 247 & not at LDL-C goal & led by NCEP ATP III \\
\hline $\begin{array}{l}030 \\
{[40]}\end{array}$ & $\begin{array}{c}\text { A } 10+E Z \\
\text { Doubling A to } 20\end{array}$ & 171 & 145 & 159 & 146 & $130 \mathrm{mg} / \mathrm{dL}$ & not specified \\
\hline $\begin{array}{l}038 \\
{[11]}\end{array}$ & $\begin{array}{c}\text { PBO, EZ } \\
\text { EZ/S } 10,20,40,80 \\
\text { S } 10,20,40,80\end{array}$ & 307 & 315 & 296 & 313 & $145 \mathrm{mg} / \mathrm{dL}$ & $250 \mathrm{mg} / \mathrm{dL}$ \\
\hline $\begin{array}{l}040 \\
{[18]}\end{array}$ & $\begin{array}{l}\text { Ongoing statin + PBO } \\
\text { Ongoing statin + EZ }\end{array}$ & 510 & 500 & 1073 & 947 & not at LDL-C goal & ed by NCEP ATP III \\
\hline $\begin{array}{l}051 \\
{[41]}\end{array}$ & $\begin{array}{c}\text { EZ/S } 10,20,40,80 \\
\text { A } 10,20,40,80\end{array}$ & 498 & 453 & 496 & 455 & not at LDL-C goal & led by NCEP ATP III \\
\hline $\begin{array}{l}058 \\
{[42]}\end{array}$ & $\begin{array}{c}\text { EZ/S } 10,20,40,80 \\
\quad \text { R } 10,20,40\end{array}$ & 624 & 857 & 678 & 800 & $145 \mathrm{mg} / \mathrm{dL}$ & $250 \mathrm{mg} / \mathrm{dL}$ \\
\hline $\begin{array}{l}077 \\
{[43]}\end{array}$ & $\begin{array}{l}\text { EZ/S 20, } 40 \\
\text { A } 10,20,40\end{array}$ & 361 & 374 & 221 & 273 & $100 \mathrm{mg} / \mathrm{dL}$ & not specified \\
\hline $\begin{array}{l}\mathbf{0 7 9} \\
{[12]}\end{array}$ & $\begin{array}{c}\text { A } 20+E Z \\
\text { Doubling to A } 40\end{array}$ & 49 & 49 & 58 & 40 & $100 \mathrm{mg} / \mathrm{dL}$ & $160 \mathrm{mg} / \mathrm{dL}$ \\
\hline $\begin{array}{l}090 \\
{[16]}\end{array}$ & $\begin{array}{c}\text { A } 40+E Z \\
\text { Doubling to A } 80\end{array}$ & 178 & 113 & 173 & 115 & 70 mg/dL & $160 \mathrm{mg} / \mathrm{dL}$ \\
\hline $\begin{array}{l}107 \\
{[20]}\end{array}$ & $\begin{array}{l}\text { EZ/S 20, } 40 \\
\text { A } 10,20,40 \\
\end{array}$ & 379 & 307 & 266 & 191 & $\begin{array}{c}70 \mathrm{mg} / \mathrm{dL} \\
100 \mathrm{mg} / \mathrm{dL}\end{array}$ & not specified \\
\hline $\begin{array}{l}112 \\
{[22]}\end{array}$ & $\begin{array}{l}\text { A } 10+E Z \\
\text { A } 20 / 40\end{array}$ & 249 & 277 & 241 & 286 & $\begin{array}{c}70 \mathrm{mg} / \mathrm{dL} \\
100 \mathrm{mg} / \mathrm{dL}\end{array}$ & $160 \mathrm{mg} / \mathrm{dL}$ \\
\hline $\begin{array}{l}679 \\
{[44]}\end{array}$ & $\begin{array}{c}\text { PBO, EZ } \\
L \text { 10, 20, } 40 \\
\text { EZ+L 10,20,40 }\end{array}$ & 88 & 132 & 86 & 106 & $145 \mathrm{mg} / \mathrm{dL}$ & $250 \mathrm{mg} / \mathrm{dL}$ \\
\hline $\begin{array}{l}691 \\
{[17]}\end{array}$ & $\begin{array}{c}\text { PBO, EZ } \\
P \quad 10,20,40 \\
\text { EZ+P 10, 20,40 }\end{array}$ & 101 & 104 & 83 & 121 & $145 \mathrm{mg} / \mathrm{dL}$ & $250 \mathrm{mg} / \mathrm{dL}$ \\
\hline $\begin{array}{l}692 \\
{[45]}\end{array}$ & $\begin{array}{c}\text { PBO, EZ } \\
\text { A } 10,20,40,80 \\
\text { EZ+A } 10,20,40,80\end{array}$ & 95 & 153 & 107 & 148 & $145 \mathrm{mg} / \mathrm{dL}$ & $250 \mathrm{mg} / \mathrm{dL}$ \\
\hline $\begin{array}{l}700 \\
{[46]}\end{array}$ & $\begin{array}{c}\mathrm{S} 20+\mathrm{EZ} \\
\text { Double S to } 40\end{array}$ & 19 & 15 & 33 & 33 & $130 \mathrm{mg} / \mathrm{dL}$ & not specified \\
\hline $\begin{array}{l}801 \\
{[23]}\end{array}$ & $\begin{array}{l}\text { S } 10,20+\text { PBO } \\
\text { S } 10,20+E Z\end{array}$ & 158 & 52 & 145 & 63 & $101 \mathrm{mg} / \mathrm{dL}$ & $160 \mathrm{mg} / \mathrm{dL}$ \\
\hline $\begin{array}{l}802 \\
{[47]}\end{array}$ & $\begin{array}{c}\text { S } 10,20+\text { PBO } \\
\text { S } 10,20+E Z\end{array}$ & 124 & 57 & 124 & 57 & $101 \mathrm{mg} / \mathrm{dL}$ & $160 \mathrm{mg} / \mathrm{dL}$ \\
\hline $\begin{array}{c}803 / 804 \\
{[24]}\end{array}$ & $\begin{array}{l}\text { A } 10,20+\text { PBO } \\
\text { A } 10,20+E Z\end{array}$ & 157 & 73 & 153 & 67 & $101 \mathrm{mg} / \mathrm{dL}$ & $160 \mathrm{mg} / \mathrm{dL}$ \\
\hline $\begin{array}{l}806 \\
{[48]}\end{array}$ & $\begin{array}{c}E Z / S 20 \\
\text { Doubling to A } 20\end{array}$ & 128 & 86 & 141 & 80 & $101 \mathrm{mg} / \mathrm{dL}$ & $160 \mathrm{mg} / \mathrm{dL}$ \\
\hline $\begin{array}{l}807 \\
{[49]}\end{array}$ & $\begin{array}{c}\text { EZ/S 20, } 40 \\
\text { Doubling to A } 20\end{array}$ & 108 & 111 & 224 & 218 & not specified & not specified \\
\hline
\end{tabular}


Table 1 Characteristics of studies included in the pooled analyses (Continued)

\begin{tabular}{cccccccc}
\hline $\begin{array}{c}\mathbf{8 0 9} \\
{[13]}\end{array}$ & $\begin{array}{c}\text { EZ/S 20 } \\
\text { R10 }\end{array}$ & 185 & 119 & 185 & 129 & $100 \mathrm{mg} / \mathrm{dL}$ & $160 \mathrm{mg} / \mathrm{dL}$ \\
\hline $\begin{array}{c}\mathbf{2 1 7 3 / 2 2 4 6} \\
{[14]}\end{array}$ & $\begin{array}{c}\text { Ongoing statin + EZ } \\
\text { Ongoing statin+ PBO }\end{array}$ & 221 & 169 & 222 & 157 & not at LDL-C goal as defined by NCEP ATP III \\
\hline $\mathbf{3 3 7 7}$ & $\begin{array}{c}\text { EZ+S 20 } \\
\text { S 20 }\end{array}$ & 47 & 76 & 48 & 76 & $145 \mathrm{mg} / \mathrm{dL}$ & $250 \mathrm{mg} / \mathrm{dL}$ \\
\hline
\end{tabular}

A = atorvastatin; EZ = ezetimibe; L = lovastatin; LDL-C = low-density lipoprotein cholesterolemia; NCEP ATP III = National Cholesterol Education Program Adult Treatment Panel III; $\mathrm{P}=$ pravastatin $=\mathrm{S}=$ simvastatin

baseline measurement. Safety was evaluated in all patients as treated; however, laboratory adverse experiences were analyzed in patients who had at least 1 postbaseline assessment.

Consistency of treatment effect among men and women was tested with analysis of covariance with terms for treatment, first-/second-line lipid-lowering therapy status, race, sex, coronary heart disease (CHD), statin potency, age, body mass index, baseline LDL-C, baseline HDL-C, baseline triglycerides, baseline response variable, diabetes, trial within first-/second-line lipidlowering therapy status, treatment by first-/second-line lipid-lowering therapy status, and treatment by sex interactions. Statistical tests were two-sided and a pvalue of less than 0.05 was considered significant. However, due to the large population size, even very small differences may be statistically significant, although not clinically relevant. Therefore, inferential statistics were not included for baseline values.

Statin potency was defined on the basis of LDL-C reduction as low potency: simvastatin $10 \mathrm{mg}$, lovastatin $10-20 \mathrm{mg}$, pravastatin $10-20 \mathrm{mg}$, fluvastatin $10-40 \mathrm{mg}$, and cerivastatin $0.2-0.3 \mathrm{mg}$; medium potency: simvastatin $20-40 \mathrm{mg}$, atorvastatin $10-20 \mathrm{mg}$, lovastatin $40-80$ $\mathrm{mg}$, pravastatin $40-80 \mathrm{mg}$, fluvastatin $80-160 \mathrm{mg}$, cerivastatin $0.4-0.8 \mathrm{mg}$, and rosuvastatin $5 \mathrm{mg}$; high potency: simvastatin $80 \mathrm{mg}$, atorvastatin $40-80 \mathrm{mg}$, rosuvastatin 10-40 $\mathrm{mg}$. The $\%$ of men and women, adjusted odds ratios, and 95\% confidence intervals (CIs) were calculated using a logistic model with terms for first-/second-line therapy, gender, treatment, and baseline value to evaluate the between-treatment ability to achieve specified treatment levels in the full cohort and with terms for first-/second-line therapy, treatment, and baseline value in each sex subgroup. No adjustments were made for multiplicity. Due to the large population size, the results of these analyses should be interpreted with caution, since statistical significance may not always imply clinical significance.

\section{Results}

A total of 22,231 patients were included in the safety analysis and 21,794 patients were included in the modified intent-to-treat population for the efficacy analysis.
Subjects received the following active treatment regimens during the studies: simvastatin: $\mathrm{n}=2148$; atorvastatin: $\mathrm{n}=4433$; rosuvastatin: $\mathrm{n}=1725$; lovastatin: $\mathrm{n}=$ 220; pravastatin: $\mathrm{n}=205$; unspecified statin: $\mathrm{n}=1577$; ezetimibe+simvastatin: $\mathrm{n}=2372$; ezetimibe+atorvastatin: $\mathrm{n}=4226$; ezetimibe+rosuvastatin: $\mathrm{n}=1723$; ezetimibe +lovastatin: $\mathrm{n}=192$; ezetimibe+pravastatin: $\mathrm{n}=205$; ezetimibe+unspecified statin: $\mathrm{n}=2760$ (Table 1 ).

Baseline demographics were generally similar, although risk factors differed somewhat between the sexes: More women vs. men had body mass index $\geq 30$ $\mathrm{kg} / \mathrm{mg}^{2}$, more women vs. men had metabolic syndrome or diabetes mellitus, more men vs. women had CHD, and at study entry, more men vs. women were being treated with ongoing statin therapy (Table 2). Baseline lipid and hs-CRP levels were generally higher in women compared with men, except for lipid ratios, which were generally similar between sexes (Table 2).

As seen in the individual studies, the overall population demonstrated significant reductions in LDL-C, nonHDL-C, triglycerides, apolipoprotein B, and hs-CRP. Significantly greater reductions were observed in subjects treated with combination statin + ezetimibe vs. statin monotherapy (all p $<0.0001$; data not shown). All between-treatment differences were statistically significant for both sexes (all $\mathrm{p}<0.001$ except apolipoprotein A-I in men $=0.0389$; Figure 1). Lipid responses to statins were similar for both sexes; however, men who received ezetimibe + statin combination experienced a significantly greater change in LDL-C $(\mathrm{p}=0.0066)$, nonHDL-C, total cholesterol, triglycerides, HDL-C, apolipoprotein A-I (all p $<0.0001)$ and apolipoprotein B ( $\mathrm{p}=$ 0.0055 ) compared with women who received ezetimibe + statin combination (Figure 1), although these differences were small $(\leq 2 \%)$ and the clinical relevance could be debated. There was no significant effect of sex on the changes in the lipid ratios or hs-CRP (all p > 0.05; Figure 1).

Figures 2 and 3 show the percentage of patients achieving single and dual lipid and hs-CRP levels by sex. When comparing men vs. women, the odds of achieving LDL-C $<100 \mathrm{mg} / \mathrm{dL}$, apolipoprotein B $<90 \mathrm{mg} / \mathrm{dL}$ and the dual target [LDL-C $<100 \mathrm{mg} / \mathrm{dL} \&$ apolipoprotein $\mathrm{B}$ $<90 \mathrm{mg} / \mathrm{dL}$ ] was significantly greater for women, 
Table 2 Baseline demographics, risk factors and clinical characteristics

\begin{tabular}{|c|c|c|c|c|}
\hline & \multicolumn{2}{|c|}{ Male } & \multicolumn{2}{|c|}{ Female } \\
\hline & $\begin{array}{c}\text { Statin } \\
(n=5279)\end{array}$ & $\begin{array}{l}\text { Statin + EZ } \\
(\mathrm{n}=6016)\end{array}$ & $\begin{array}{c}\text { Statin } \\
(n=5029)\end{array}$ & $\begin{array}{l}\text { Statin + EZ } \\
(n=5470)\end{array}$ \\
\hline Mean age, years (SD) & $58.4(11.22)$ & $59.2(11.14)$ & $60.0(11.23)$ & $60.7(11.01)$ \\
\hline \multicolumn{5}{|l|}{ Age, n (\%) } \\
\hline$<65$ years & $3556(67.4)$ & $3909(65.0)$ & $3126(62.2)$ & $3341(61.1)$ \\
\hline $65-74$ years & $1361(25.8)$ & $1614(26.8)$ & $1457(29.0)$ & $1557(28.5)$ \\
\hline$\geq 75$ years & $362(6.9)$ & $493(8.2)$ & $446(8.9)$ & $572(10.5)$ \\
\hline Caucasian, n (\%) & $4549(86.2)$ & $5187(86.2)$ & $4141(82.3)$ & 4519 (82.6) \\
\hline $\mathrm{BMI}<30$ kg/m² (\%) & $3287(63.2)$ & $3728(62.8)$ & $2721(55.0)$ & $3056(56.7)$ \\
\hline $\mathrm{CHD}, \mathrm{n}(\%)$ & $2129(40.3)$ & $2614(43.5)$ & $1181(23.5)$ & $1501(27.5)$ \\
\hline Diabetes, n (\%) & $1491(28.2)$ & $1732(28.8)$ & 1591 (31.6) & 1727 (31.6) \\
\hline Metabolic syndrome & $1912(46.5)$ & $2112(45.8)$ & $2321(54.7)$ & $2406(53.6)$ \\
\hline Ongoing Statin*, n (\%) & $2271(43.0)$ & $2935(48.8)$ & $1780(35.4)$ & $2310(42.2)$ \\
\hline Least squares mean (SD) & $(n=5279)$ & $(n=6016)$ & $(n=5029)$ & $(n=5470)$ \\
\hline LDL-C (mg/dL) & $147.0(40.3)$ & $144.4(39.8)$ & $156.4(41.7)$ & $154.2(42.5)$ \\
\hline $\mathrm{HDL}-\mathrm{C}(\mathrm{mg} / \mathrm{dL})$ & $45.8(10.5)$ & $45.7(10.3)$ & $53.4(12.7)$ & $53.7(13.0)$ \\
\hline non-HDL-C (mg/dL) & $180.2(44.5)$ & $177.5(44.0)$ & $190.1(45.8)$ & $187.6(46.4)$ \\
\hline $\mathrm{TC}(\mathrm{mg} / \mathrm{dL})$ & $226.0(44.0)$ & $223.2(43.6)$ & $243.6(45.7)$ & $241.3(46.2)$ \\
\hline Triglycerides (mg/dL) ${ }^{\ddagger}$ & $150.0(88.1)$ & $151.0(87.9)$ & $156.5(90.2)$ & $154.0(90.7)$ \\
\hline Apo B (mg/dL) & $142.5(32.7)$ & $141.3(32.3)$ & $147.9(34.0)$ & $146.4(34.4)$ \\
\hline Apo Al (mg/dL) & $146.3(23.2)$ & $146.4(23.8)$ & $164.2(27.5)$ & $165.0(28.0)$ \\
\hline hs-CRP (mg/L) ${ }^{\ddagger}$ & $1.8(2.7)$ & $1.8(2.7)$ & $2.7(4.1)$ & $2.8(4.1)$ \\
\hline non-HDL-C/HDL-C & $4.1(1.5)$ & $4.1(1.4)$ & $3.8(1.4)$ & $3.7(1.4)$ \\
\hline Apo B/Apo Al & $1.0(0.3)$ & $1.0(0.3)$ & $0.9(0.3)$ & $0.9(0.3)$ \\
\hline LDL-C/HDL-C & $3.4(1.2)$ & $3.3(1.2)$ & $3.1(1.1)$ & $3.0(1.1)$ \\
\hline TC/HDL-C & $5.2(1.5)$ & $5.1(1.4)$ & $4.8(1.4)$ & $4.7(1.4)$ \\
\hline
\end{tabular}

$\mathrm{Apo}=$ Apolipoprotein; $\mathrm{BMI}=$ body mass index; $\mathrm{CHD}=$ coronary heart disease; $\mathrm{EZ}=$ ezetimibe; $\mathrm{LDL}-\mathrm{C}=$ low-density lipoprotein cholesterol; HDL-C = high-density lipoprotein cholesterol; hs-CRP = high-sensitivity C-reactive protein; SD = standard deviation; TC = total cholesterol

*Patients who entered a study who were already receiving statin treatment prior to screening

${ }^{\ddagger}$ presented as median values (robust SD); p-values based on ANOVA model using Tukey scores transformed values with term for gender.

although the differences were small (Table 3). Conversely, the odds of achieving hs-CRP $<1 \mathrm{mg} / \mathrm{L}$, hs-CRP $<$ $2 \mathrm{mg} / \mathrm{L}$ and dual specified levels of [LDL-C $<100 \mathrm{mg} /$ $\mathrm{dL}$ and hs-CRP $<2 \mathrm{mg} / \mathrm{L}$ ] were significantly greater for men than for women, and those differences were also small (Table 3). Of note, the odds ratios and $95 \%$ confidence intervals (Table 3) are calculated from the model with terms for first-/second-line therapy, sex, treatment and baseline LDL-C. The baseline is adjusted and the statistics are comparing all women versus all men attaining specified targets, and not by treatment group. When comparing by treatment group in both men and women, the odds of achieving all single and dual specified targets was greater in subjects treated with the combination statin + ezetimibe compared with statin monotherapy (Table 4).

A summary of adverse events is listed in Table 5. When comparing the full cohort, both treatments had generally similar tolerability and safety profiles (i.e., there were no between-treatment differences in adverse events, liver enzymes, or creatine kinase elevations). There were significantly more alanine aminotransferase (ALT) elevations $\geq 3 \times$ upper limit of normal reported in the combination treatment group compared with statin monotherapy, and although there was no statistically significant effect of sex, this difference was primarily driven by elevations in males (Table 5). When comparing the sexes, women reported significantly more adverse events (i.e., $\geq 1$ adverse event), drug-related adverse events, gall-bladder-related adverse events, gastrointestinal-related adverse events, allergic reaction or rash-related adverse events; and more women discontinued due to adverse events and drugrelated adverse events, although there were no significant differences between treatments (Table 5). Compared with women, men reported significantly more creatine kinase elevations $\geq 10 \times$ upper limit of normal (no differences between treatments) and hepatitis-related adverse events, of which there were significantly more in the combination group vs. the statin monotherapy group (Table 5). There were 7 cases of myopathy reported, with no significant differences between treatments or sexes in their occurrence, and no cases of rhabdomyolysis reported (Table 5). A total 


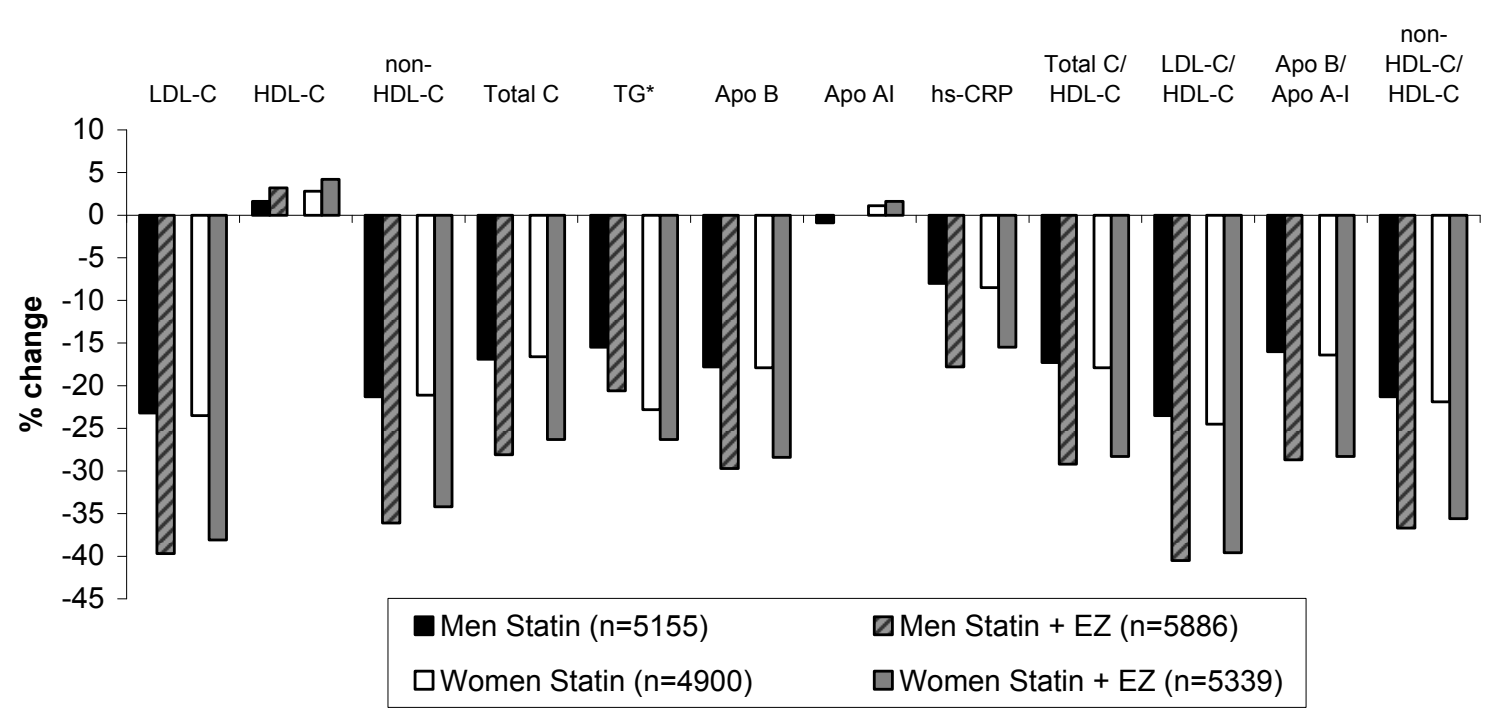

Figure 1 Percent change in lipid, lipid ratio, and hs-CRP levels in male and female patients. All between-treatment differences were $p<$ 0.0001 except for Apo A-I, for which the between treatment difference in women was $p=0.0009$ and in men was $p=0.0389$.

of 12 deaths were reported (5 in the statin group and 7 in the statin + ezetimibe group) during the course of all 27 studies and none of the deaths were attributed to treatment.

\section{Discussion}

The results of this pooled analysis demonstrated that in general, the response to statins was similar for both men and women. Men had slightly greater lipid responses to the ezetimibe + statin combination compared with women, but the clinical relevance of this is questionable. When comparing women and men, the odds were greater for women vs. men in the attainment of specified LDL-C and apolipoprotein B targets, while the odds of achieving specified hs-CRP targets was greater for men vs. women. In the full cohort and in

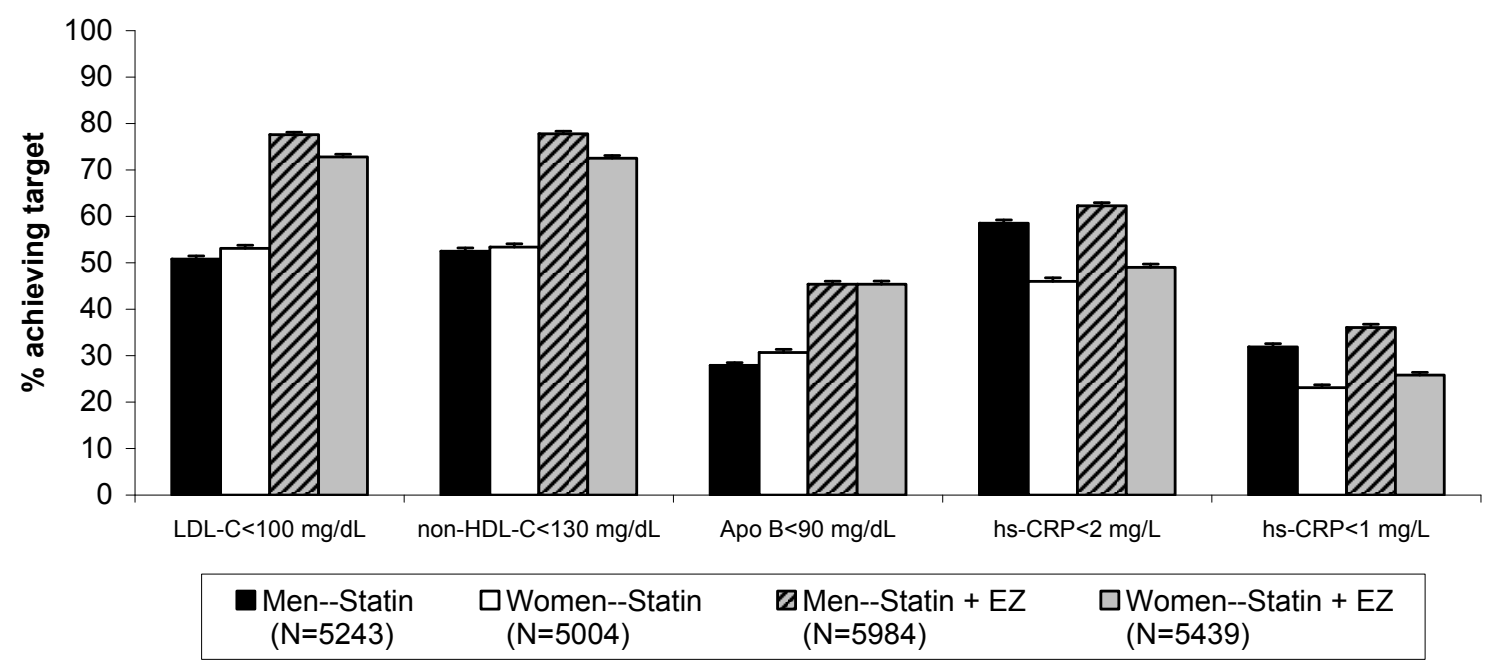

Figure 2 Percent of patients by sex achieving specified single lipid and hs-CRP levels. Error bars represent standard error 


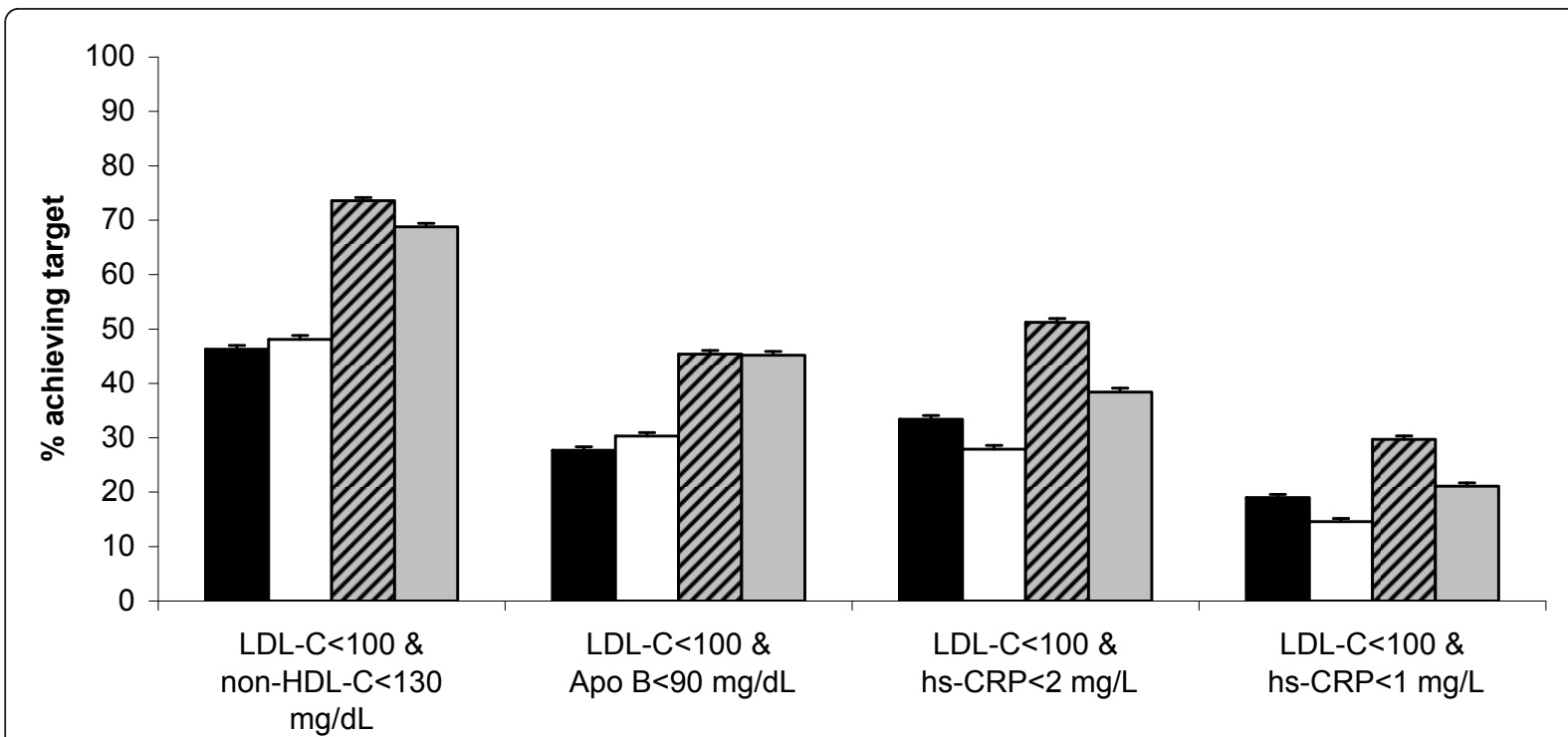

\begin{tabular}{|ll|}
\hline Men--Statin (N=5243) & $\square$ Women--Statin (N=5004) \\
$\square$ Men--Statin + EZ (N=5984) & $\square$ Women--Statin + EZ (N=5439)
\end{tabular}

Figure 3 Percent of patients by sex achieving dual specified lipid and hs-CRP levels. Error bars represent standard error.

both sexes, achievement of specified single and dual lipid levels was greater with statin + ezetimibe vs. statin. The tolerability profiles were generally similar between sexes and treatments. The differences reported here are small. In addition, there was no significant effect of sex on the changes in the lipid ratios, supporting the perspective that the small differences in LDL-C response observed are not likely to translate into clinically meaningful differences. These findings suggest any potential sex differences that may exist in response to lipid-lowering therapy and achievement of specified lipid and hs-

Table 3 Adjusted odds ratios and $95 \%$ confidence intervals* in females vs males

\begin{tabular}{|c|c|}
\hline & Female vs. Male \\
\hline $\mathrm{LDL}-\mathrm{C}<100 \mathrm{mg} / \mathrm{dL}$ & $1.09(1.02,1.17)$ \\
\hline non-HDL-C $<130$ mg/dL & $1.03(0.96,1.10)$ \\
\hline Apo $B<90 \mathrm{mg} / \mathrm{dL}$ & $1.14(1.07,1.22)$ \\
\hline hs-CRP $<2$ mg/L & $0.76(0.71,0.82)$ \\
\hline hs-CRP $<1 \mathrm{mg} / \mathrm{dL}$ & $0.86(0.80,0.93)$ \\
\hline LDL-C $<100 \&$ non-HDL-C $<130$ mg/dL & $1.07(1.00,1.14)$ \\
\hline LDL-C $<100 \&$ Apo B $<90$ mg/dL & $1.11(1.04,1.19)$ \\
\hline LDL-C < 100 \& hs-CRP $<2$ mg/L & $0.90(0.84,0.97)$ \\
\hline LDL-C $<100 \&$ hs-CRP $<1$ mg/L & $0.99(0.91,1.07)$ \\
\hline
\end{tabular}

Apo = Apolipoprotein; EZ = ezetimibe; LDL-C = low-density lipoprotein cholesterol; $\mathrm{HDL}-\mathrm{C}=$ high-density lipoprotein cholesterol; hs-CRP = highsensitivity C-reactive protein

* Ratio of the predictive odds of attaining target in female versus male patients is based on the logistic model with terms for first/second line, sex, treatment, and baseline value(s).
CRP levels, should unlikely account for the care gaps reported in the literature $[4,10]$. These data should be considered when planning and assessing such treatment in men and women.

Analyses of changes in LDL-C by sex subgroups have been presented in several previous reports and demonstrated that men and women responded to treatment similarly to the overall population [11-22]. In those studies, the subgroups by sex were relatively small; and although the analyses of change in LDL-C were prespecified, they were not powered to show statistical differences between the sex subgroups. Moreover, previous

Table 4 Adjusted odds ratios and $95 \%$ confidence intervals for between-treatment comparisons*

\begin{tabular}{ll}
\hline LDL-C $<100 \mathrm{mg} / \mathrm{dL}$ & $5.29(4.79,5.84)$ \\
non-HDL-C $<130 \mathrm{mg} / \mathrm{dL}$ & $5.08(4.59,5.61)$ \\
Apo $\mathrm{B}<90 \mathrm{mg} / \mathrm{dL}$ & $3.30(2.98,3.64)$ \\
$\mathrm{hs}-\mathrm{CRP}<2 \mathrm{mg} / \mathrm{L}$ & $1.22(1.12,1.34)$ \\
hs-CRP $<1 \mathrm{mg} / \mathrm{dL}$ & $1.26(1.15,1.39)$ \\
$\mathrm{LDL}-\mathrm{C}<100 \& \mathrm{non}-\mathrm{HDL}-\mathrm{C}<130 \mathrm{mg} / \mathrm{dL}$ & $5.18(4.70,5.70)$ \\
$\mathrm{LDL}-\mathrm{C}<100 \&$ Apo B $<90 \mathrm{mg} / \mathrm{dL}$ & $3.34(3.02,3.69)$ \\
$\mathrm{LDL}-\mathrm{C}<100 \&$ hs-CRP $<2 \mathrm{mg} / \mathrm{L}$ & $2.52(2.30,2.77)$ \\
$\mathrm{LDL}-\mathrm{C}<100 \&$ hs-CRP $<1 \mathrm{mg} / \mathrm{L}$ & $2.05(1.84,2.28)$ \\
\hline
\end{tabular}

Apo = Apolipoprotein; EZ = ezetimibe; LDL-C = low-density lipoprotein cholesterol; $\mathrm{HDL}-\mathrm{C}=$ high-density lipoprotein cholesterol; hs-CRP = highsensitivity C-reactive protein

* Ratio of the predictive odds of attaining target on Statin+EZ versus statin based on the logistic model with terms for first/second line, treatment, and baseline value(s). 
Table 5 Adverse event summary

\begin{tabular}{|c|c|c|c|c|c|c|c|c|c|c|}
\hline \multirow{3}{*}{$\begin{array}{l}\text { Adverse events, } \mathrm{n} \\
\text { (\%) }\end{array}$} & \multicolumn{2}{|c|}{ Full Cohort } & \multirow{3}{*}{$\begin{array}{l}\text { Between } \\
\text { treatment } p \text { - } \\
\text { value }\end{array}$} & \multicolumn{2}{|c|}{ Male } & \multicolumn{5}{|c|}{ Female } \\
\hline & Statin & Statin/EZ & & $\begin{array}{l}\text { P-value } \\
\text { for effect } \\
\text { of sex }\end{array}$ & Statin & statin/EZ & $\begin{array}{l}\text { Between } \\
\text { Treatment } \\
\mathrm{p} \text {-value }\end{array}$ & Statin & Statin/EZ & $\begin{array}{c}\text { Between } \\
\text { treatment } \\
\text { p-value }\end{array}$ \\
\hline & $N=10517$ & $N=11714$ & & & $N=5380$ & $N=6129$ & & $N=5137$ & $N=5585$ & \\
\hline$\geq 1$ & $3455(32.9)$ & $3717(31.7)$ & 0.849 & $<0.001$ & $\begin{array}{l}1537 \\
(28.6)\end{array}$ & $\begin{array}{l}1779 \\
(29.0)\end{array}$ & 0.173 & $\begin{array}{l}1918 \\
(37.3)\end{array}$ & $\begin{array}{l}1938 \\
(34.7)\end{array}$ & 0.114 \\
\hline Drug related* & $833(7.9)$ & $961(8.2)$ & 0.181 & $<0.001$ & $349(6.5)$ & $456(7.4)$ & 0.025 & $484(9.4)$ & $505(9.0)$ & 0.819 \\
\hline Serious & $145(1.4)$ & $187(1.6)$ & 0.220 & 0.370 & $74(1.4)$ & $107(1.7)$ & 0.122 & $71(1.4)$ & $80(1.4)$ & 0.091 \\
\hline Serious drug related & $6(0.1)$ & $13(0.1)$ & 0.148 & 0.908 & $2(0.0)$ & $8(0.1)$ & 0.075 & $4(0.1)$ & $5(0.1)$ & 0.784 \\
\hline $\begin{array}{l}\text { Discontinuations }{ }^{\dagger} \\
\text { due to } A E s\end{array}$ & $219(2.1)$ & $263(2.2)$ & 0.286 & $<0.001$ & $91(1.7)$ & $105(1.7)$ & 0.828 & $128(2.5)$ & $158(2.8)$ & 0.229 \\
\hline $\begin{array}{l}\text { Drug } \\
\text { related* }\end{array}$ & $136(1.3)$ & $177(1.5)$ & 0.117 & $<0.001$ & $49(0.9)$ & $69(1.1)$ & 0.234 & $87(1.7)$ & $108(1.9)$ & 0.288 \\
\hline Serious & $34(0.3)$ & $38(0.3)$ & 0.906 & 0.320 & $18(0.3)$ & $23(0.4)$ & 0.659 & $16(0.3)$ & $15(0.3)$ & 0.746 \\
\hline $\begin{array}{l}\text { Serious } \\
\text { drug } \\
\text { related }\end{array}$ & $6(0.1)$ & $7(0.1)$ & 0.864 & 0.749 & $2(0.0)$ & $4(0.1)$ & 0.485 & $4(0.1)$ & $3(0.1)$ & 0.689 \\
\hline Deaths & $5(0.0)$ & $7(0.1)$ & 0.702 & 0.655 & $4(0.1)$ & $3(0.0)$ & 0.582 & $1(0.0)$ & $4(0.1)$ & 0.197 \\
\hline $\begin{array}{l}\text { Gastrointestinal- } \\
\text { related }^{\ddagger}\end{array}$ & $861(8.2)$ & $889(7.6)$ & 0.367 & $<0.001$ & $339(6.3)$ & $390(6.4)$ & 0.636 & $522(10.2)$ & $499(8.9)$ & 0.113 \\
\hline $\begin{array}{l}\text { Gallbladder- } \\
\text { related }^{\S}\end{array}$ & $9(0.1)$ & $11(0.1)$ & 0.824 & 0.014 & $2(0.0)$ & $3(0.0)$ & 0.754 & $7(0.1)$ & $8(0.1)$ & 0.940 \\
\hline $\begin{array}{l}\text { Allergic reaction } \\
\text { or rash }\end{array}$ & $175(1.7)$ & $213(1.8)$ & 0.194 & $<0.001$ & $70(1.3)$ & $90(1.5)$ & 0.326 & $105(2.0)$ & $123(2.2)$ & 0.382 \\
\hline $\begin{array}{l}\text { Hepatitis- } \\
\text { related" }\end{array}$ & $24(0.2)$ & $39(0.3)$ & 0.079 & 0.030 & $13(0.2)$ & $27(0.4)$ & 0.038 & $11(0.2)$ & $12(0.2)$ & 0.858 \\
\hline $\begin{array}{l}\text { ALT } \geq 3 \times \text { ULN, } \\
\text { consecutive, m/n (\%) }\end{array}$ & $\begin{array}{c}31 / 10341 \\
(0.3)\end{array}$ & $\begin{array}{c}50 / 11512 \\
(0.4)\end{array}$ & 0.519 & 0.241 & $\begin{array}{l}15 / 5289 \\
(0.3)\end{array}$ & $\begin{array}{c}34 / 6031 \\
(0.6)\end{array}$ & 0.111 & $\begin{array}{c}16 / 5052 \\
(0.3)\end{array}$ & $\begin{array}{c}16 / 5481 \\
(0.3)\end{array}$ & 0.611 \\
\hline $\begin{array}{l}\text { AST } \geq 3 \times \text { ULN, } \\
\text { consecutive, } \mathrm{m} / \mathrm{n}(\%)\end{array}$ & $\begin{array}{c}23 / 10342 \\
(0.2)\end{array}$ & $\begin{array}{c}30 / 11512 \\
(0.3)\end{array}$ & 0.087 & 0.100 & $\begin{array}{l}7 / 5290 \\
(0.1)\end{array}$ & $\begin{array}{l}16 / 6031 \\
(0.3)\end{array}$ & 0.018 & $\begin{array}{l}16 / 5052 \\
(0.3)\end{array}$ & $\begin{array}{l}14 / 5481 \\
(0.3)\end{array}$ & 0.873 \\
\hline $\begin{array}{l}\text { ALT or AST } \geq 3 \times \\
\text { ULN, consecutive, } \\
\mathrm{m} / \mathrm{n}(\%)\end{array}$ & $\begin{array}{c}36 / 10342 \\
(0.3)\end{array}$ & $\begin{array}{c}64 / 11512 \\
(0.6)\end{array}$ & 0.018 & 0.185 & $\begin{array}{c}17 / 5290 \\
(0.3)\end{array}$ & $\begin{array}{c}41 / 6031 \\
(0.7)\end{array}$ & 0.006 & $\begin{array}{c}19 / 5052 \\
(0.4)\end{array}$ & $\begin{array}{c}23 / 5481 \\
(0.4)\end{array}$ & 0.649 \\
\hline $\begin{array}{l}\mathrm{CK} \geq 10 \times \mathrm{ULN}, \mathrm{m} / \mathrm{n} \\
(\%)\end{array}$ & $\begin{array}{c}13 / 10342 \\
(0.1)\end{array}$ & $\begin{array}{l}9 / 11514 \\
(0.1)\end{array}$ & 0.337 & 0.028 & $\begin{array}{c}9 / 5290 \\
(0.2)\end{array}$ & $\begin{array}{c}7 / 6033 \\
(0.1)\end{array}$ & 0.543 & $\begin{array}{c}4 / 5052 \\
(0.1)\end{array}$ & $\begin{array}{c}2 / 5481 \\
(0.0)\end{array}$ & 0.395 \\
\hline Myopathy", m/n (\%) & $\begin{array}{c}4 / 10342 \\
(0.04)\end{array}$ & $\begin{array}{c}3 / 11512 \\
(0.03)\end{array}$ & 0.667 & 0.699 & $\begin{array}{l}2 / 5290 \\
(0.04)\end{array}$ & $\begin{array}{c}2 / 6031 \\
(0.02)\end{array}$ & 0.985 & $\begin{array}{l}2 / 5052 \\
(0.04)\end{array}$ & $\begin{array}{l}1 / 5481 \\
(0.02)\end{array}$ & 0.517 \\
\hline $\begin{array}{l}\text { Rhabdomyolysis^, } \\
\mathrm{m} / \mathrm{n}(\%)\end{array}$ & $\begin{array}{c}0 / 10342 \\
(0.00)\end{array}$ & $\begin{array}{c}0 / 11512 \\
(0.00)\end{array}$ & N/A & N/A & $\begin{array}{c}0 / 5290 \\
(0.00)\end{array}$ & $\begin{array}{l}0 / 6031 \\
(0.00)\end{array}$ & N/A & $\begin{array}{c}0 / 5052 \\
(0.00)\end{array}$ & $\begin{array}{c}0 / 5481 \\
(0.00)\end{array}$ & N/A \\
\hline
\end{tabular}

$\mathrm{ALT}=$ alanine aminotransferase, $\mathrm{ALT}=$ aspartate aminotransferase, $\mathrm{CK}=$ creatine kinase ULN $=$ upper limit of normal

$\%=\mathrm{m} / \mathrm{n} \times 100=$ (number of patients within the AE category/number of treated patients) $\times 100$

*Determined by the investigator to be related to the drug

${ }^{\dagger}$ Study medication withdrawn

${ }^{\ddagger}$ For gastrointestinal-related clinical adverse events, the preferred terms (preferred Medra terms) were pre-identified for collective review, including e.g. abdominal discomfort, abdominal distension, abdominal pain, abdominal tenderness, colitis, colonic polyp, constipation, dental caries, dental discomfort, diarrhoea, diverticulum, duodenitis, dyspepsiea, dysphagia, erosive duodenitis, faeces discolored, flatulence, flood poisoning, gastitis, gastoesophageal reflux disease, gingival pain, haemorrhoids, hiatus hernia, nausea, oesophageal stenosis, rectal haemorrhage, tooth loss, toothache, and vomiting.

${ }^{s}$ For gallbladder-related clinical adverse events the preferred terms (preferred Medra terms) were pre-identified for collective review, including e.g. bile duct obstruction, bile duct stenosis, bile duct stone, biliary colic, cholangitis, cholecystectomy, cholecystitis, cholelithiasis, gallbladder disorder, and gallbladder perforation

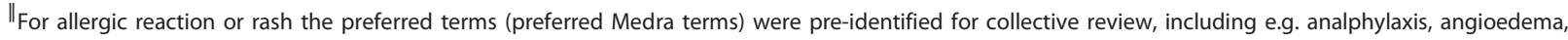
dermatitis, dermagraphism, drug hypersensitivity, eczema, eosinophilia, erythema, face oedema, hypersensitivity, palmar erythema, periorbital oedema, photodermatosis, photosensitivity, pigmentation disorder, pruritis, rash, rosacea, skin disorder, skin exfoliation, skin hyperpigmentation, skin inflammation, skin lesion, subcutaneious nodule, systemic lups erythematosus rash, and urticaria

"In addition to review of the effects of ezetimibe + statin on laboratory parameters associated with liver function, potentially "hepatitis-related" clinical adverse event terms (preferred Medra terms) were pre-identified for collective review, e.g., cholestasis, hepatic necrosis, hepatocellular injury, cytolytic hepatitis, hepatitis, hepatomegaly, hepatic cyst, hepatitis cholestatic, jaundice, hepatic failure, hepatitis fulminant, jaundice cholestatic, hepatic lesion, and, hepatitis infectious.

"Myopathy is defined as CK elevation > 10XULN with associated muscle symptoms with no other explanatory cause.

$\wedge$ Rhabdomyolysis is defined as myopathy with associated evidence of renal damage. 
reports of individual studies have demonstrated no significant treatment by sex interactions for LDL-C target attainment [23-25]. The results in the current pooled analysis showed that women are $\sim 9 \%$ more likely to achieve LDL- $C<100 \mathrm{mg} / \mathrm{dL}$ than men if they were in the same first-line or second-line study with the same treatment and similar baseline LDL-C. It is important to note that this analysis was a comparison of all women vs. all men attaining LDL-C targets, and was not a betweentreatment comparison. This result may seem unusual in light of the slightly greater LDL-C reductions observed in men vs. women with ezetimibe + statin and higher baseline LDL-C levels observed in women vs. men. However, the model accounted for baseline factors, including LDLC level, first-line or second-line study, and treatment. Since the model accounts for the other factors, such as study type, the presence of diabetes or CHD, and baseline LDL-C, further study may elucidate the factors associated with greater achievement of lipid targets.

Also of interest in the current analysis were the differences in the odds of achieving specified lipid and hsCRP levels between the sexes. There were small but significant differences between men and women in the odds of attaining single specified apolipoprotein B and hs-CRP levels; the most notable of these differences being the greater odds for men vs. women achieving both specified levels of hs-CRP. The magnitude of difference between treatment groups for attainment of specified hs-CRP levels was relatively small compared with other lipid levels, and there were clear differences between the sexes in achievement of both specified hsCRP levels. Higher baseline levels of hs-CRP in women could also play a role in lower achievement in women vs. men. One could speculate that the higher levels of hs-CRP in women, both at baseline and study end, could be due to the higher prevalence of metabolic syndrome and obesity in women, the presence of which has been associated with increased levels of hs-CRP and other inflammatory markers [26].

Lipid-lowering treatment reduces coronary events [27], although the consistency of this effect in women has been controversial until recently $[28,29]$. Stronger contemporary data have provided some evidence toward answers to that debate. A meta-analysis of primary prevention trials that included sex-specific clinical outcomes in CVD demonstrated that cardiovascular events were reduced by about one-third in women after 12 months of statin treatment, during which subjects experienced a $51 \mathrm{mg} / \mathrm{dL}$ reduction from baseline in LDL-C [7]. Similar relative risk reductions were observed in men. The Cholesterol Treatment Trialists' (CTT) Collaboration showed that further reductions in LDL cholesterol produce definite further reductions in the incidence of cardiovascular events in the overall population, with a significant proportional risk reduction of $17 \%$ ( $\mathrm{p}<0.001$ ) per $39 \mathrm{mg} / \mathrm{dL}$ reduction in LDL-C among women in first major vascular events [30]. Taken together, these data support the utility of intensive lipid lowering for reducing the risk of cardiovascular events in both men and women. Though the ultimate assessment of clinical impact of lipid-lowering therapy supported by ezetimibe-related therapy awaits results of IMPROVE-IT, [31] results from SEAS and SHARP describe lower rates of ischemic cardiac events with ezetimibe-simvastatin therapy in subjects with aortic stenosis and chronic kidney disease, respectively [32-34].

Both treatments were generally well tolerated in the overall population and in both sexes. This is consistent with previous reports, which have shown generally comparable safety and tolerability profiles with statin monotherapy and ezetimibe + statin coadministration treatment $[35,36]$. In conclusion, the results of the present study underscore the utility of lipid-lowering therapy in women. The small sex-related differences in lipid-lowering therapy may not be clinically meaningful and underscore the ongoing need for appropriate management of lipid levels in women.

\section{Abbreviations}

ALT: alanine aminotransferase; CHD: coronary heart disease; Cls: confidence intervals: CVD: cardiovascular disease; HDL-C: high-density lipoprotein cholesterol; hs-CRP: high-sensitivity C-reactive protein; LDL-C: low-density lipoprotein cholesterol.

\section{Acknowledgements}

This study was funded by Merck Sharp \& Dohme Corp., Whitehouse Station, NJ, USA

The authors are grateful to Dr. Jennifer Robinson for critically reviewing the content of the manuscript and wish to thank Martha Vollmer, MA, of Merck Sharp \& Dohme Corp. for editorial assistance.

\section{Author details}

'St. Michael's Hospital, Toronto, Ontario, Canada. ${ }^{2} \mathrm{CHRU}$-Lille, Université Lille 2, Lille, France. ${ }^{3}$ Merck Sharp \& Dohme Corp., Whitehouse Station, NJ, USA.

\section{Authors' contributions}

BLA performed or supervised analyses and interpreted results, provided substantive suggestions for revision, or critically reviewed the manuscript. PB conceived, designed or planned the study, interpreted the results, and provided substantive suggestions for revision or critically reviewed the manuscript. MEH conceived, designed or planned the study, interpreted the results, wrote sections of the initial draft, and provided substantive

suggestions for revision or critically reviewed the manuscript. $J L$ collected or assembled the data, performed or supervised analyses and interpreted the results; provided substantive suggestions for revisions or critically reviewed the manuscript; provided statistical expertise. AS performed or supervised analyses and interpreted the results; provided substantive suggestions for revisions or critically reviewed the manuscript; provided statistical expertise. AMT conceived, designed or planned the study and interpreted the results; and provided substantive suggestions for revisions or critically reviewed the manuscript. All authors reviewed and approved the final version of the paper.

\section{Competing interests}

BLA has received speaker fees for various CMEs sponsored by pharmaceutical companies including Merck Sharp \& Dohme Corp. 
PB has received payment as a consultant and for lectures on behalf of Merck/Schering-Plough; and payment for development of educational presentations for Astra Zeneca.

MEH, JL, AS, and AMT are employees of Merck Sharp \& Dohme Corp and may own stock or hold stock options in the company.

Received: 28 July 2011 Accepted: 22 August 2011

Published: 22 August 2011

\section{References}

1. Lloyd-Jones DM: Short-term versus long-term risk for coronary artery disease: implications for lipid guidelines. Curr Opin Lipidol 2006, 17:619-625.

2. Mosca L, Benjamin EJ, Berra K, Bezanson JL, Dolor RJ, Lloyd-Jones DM, Newby LK, Pina IL, Roger VL, Shaw LJ, Zhao D, Beckie TM, Bushnell C, D'Armiento J, Kris-Etherton PM, Fang J, Ganiats TG, Gomes AS, Gracia CR, Haan CK, Jackson EA, Judelson DR, Kelepouris E, Lavie CJ, Moore A, Nussmeier NA, Ofili E, Oparil S, Ouyang P, Pinn WW, Sherif K, Smith SC Jr, Sopko G, Chandra-Strobos N, Urbina EM, Vaccarino V, Wenger NK. Effectiveness-based guidelines for the prevention of cardiovascular disease in women-2011 update: a guideline from the american heart association. Circulation 2011, 123:1243-1262.

3. Expert panel on detection evaluation and treatment of high blood cholesterol in adults: Executive Summary of The Third Report of The National Cholesterol Education Program (NCEP) Expert Panel on Detection, Evaluation, And Treatment of High Blood Cholesterol In Adults (Adult Treatment Panel III). JAMA 2001, 285:2486-2497.

4. Wenger NK: Lipid abnormalities in women: data for risk, data for management. Cardiol Rev 2006, 14:276-280.

5. Harris DJ, Douglas PS: Enrollment of women in cardiovascular clinical trials funded by the National Heart, Lung, and Blood Institute. N Engl J Med 2000, 343:475-480.

6. Blauwet $L A$, Redberg RF: The role of sex-specific results reporting in cardiovascular disease. Cardiol Rev 2007, 15:275-278.

7. Mora S, Glynn RJ, Hsia J, MacFadyen JG, Genest J, Ridker PM: Statins for the primary prevention of cardiovascular events in women with elevated high-sensitivity C-reactive protein or dyslipidemia: results from the Justification for the Use of Statins in Prevention: An Intervention Trial Evaluating Rosuvastatin (JUPITER) and meta-analysis of women from primary prevention trials. Circulation 2010, 121:1069-1077.

8. Hulley S, Grady D, Bush T, Furberg C, Herrington D, Riggs B, Vittinghoff E: Randomized trial of estrogen plus progestin for secondary prevention of coronary heart disease in postmenopausal women. Heart and Estrogen/ progestin Replacement Study (HERS) Research Group. JAMA 1998, 280:605-613.

9. Rossouw JE, Anderson GL, Prentice RL, LaCroix AZ, Kooperberg C, Stefanick ML, Jackson RD, Beresford SA, Howard BV, Johnson KC, Kotchen JM, Ockene J: Risks and benefits of estrogen plus progestin in healthy postmenopausal women: principal results From the Women's Health Initiative randomized controlled trial. JAMA 2002, 288:321-333.

10. Kim C, Hofer TP, Kerr EA: Review of evidence and explanations for suboptimal screening and treatment of dyslipidemia in women. A conceptual model. J Gen Intern Med 2003, 18:854-863.

11. Bays HE, Ose L, Fraser N, Tribble DL, Quinto K, Reyes R, JohnsonLevonas AO, Sapre A, Donahue SR: A multicenter, randomized, doubleblind, placebo-controlled, factorial design study to evaluate the lipidaltering efficacy and safety profile of the ezetimibe/simvastatin tablet compared with ezetimibe and simvastatin monotherapy in patients with primary hypercholesterolemia. Clin Ther 2004, 26:1758-1773.

12. Conard SE, Bays HE, Leiter LA, Bird SR, Rubino J, Lowe RS, Tomassini JE, Tershakovec AM: Efficacy and safety of ezetimibe added on to atorvastatin (20 mg) versus uptitration of atorvastatin (to $40 \mathrm{mg}$ ) in hypercholesterolemic patients at moderately high risk for coronary heart disease. Am J Cardiol 2008, 102:1489-1494.

13. Farnier M, Averna M, Missault L, Vaverkova H, Viigimaa M, Massaad R, Vandormael $K$, Johnson-Levonas AO, Brudi P: Lipid-altering efficacy of ezetimibe/simvastatin 10/20 mg compared with rosuvastatin $10 \mathrm{mg}$ in high-risk hypercholesterolaemic patients inadequately controlled with prior statin monotherapy - The IN-CROSS study. Int J Clin Pract 2009, 63:547-559.
14. Gagne C, Bays HE, Weiss SR, Mata P, Quinto K, Melino M, Cho M, Musliner TA, Gumbiner B: Efficacy and safety of ezetimibe added to ongoing statin therapy for treatment of patients with primary hypercholesterolemia. Am J Cardiol 2002, 90:1084-1091.

15. Gaudiani LM, Lewin A, Meneghini L, Perevozskaya I, Plotkin D, Mitchel Y, Shah S: Efficacy and safety of ezetimibe co-administered with simvastatin in thiazolidinedione-treated type 2 diabetic patients. Diabetes Obes Metab 2005, 7:88-97.

16. Leiter LA, Bays H, Conard S, Bird S, Rubino J, Hanson ME, Tomassini JE, Tershakovec AM: Efficacy and safety of ezetimibe added on to atorvastatin $(40 \mathrm{mg}$ ) compared with uptitration of atorvastatin (to 80 $\mathrm{mg}$ ) in hypercholesterolemic patients at high risk of coronary heart disease. Am J Cardiol 2008, 102:1495-1501.

17. Melani L, Mills R, Hassman D, Lipetz R, Lipka L, LeBeaut A, Suresh R, Mukhopadhyay $P$, Veltri E: Efficacy and safety of ezetimibe coadministered with pravastatin in patients with primary hypercholesterolemia: a prospective, randomized, double-blind trial. Eur Heart J 2003, 24:717-728.

18. Pearson TA, Denke MA, McBride PE, Battisti WP, Brady WE, Palmisano J: A community-based, randomized trial of ezetimibe added to statin therapy to attain NCEP ATP III goals for LDL cholesterol in hypercholesterolemic patients: the ezetimibe add-on to statin for effectiveness (EASE) trial. Mayo Clin Proc 2005, 80:587-595.

19. Reckless JP, Henry P, Pomykaj T, Lim ST, Massaad R, Vandormael K, Johnson-Levonas AO, Lis K, Brudi P, Allen C: Lipid-altering efficacy of ezetimibe/simvastatin 10/40 mg compared with doubling the statin dose in patients admitted to the hospital for a recent coronary event: the INFORCE study. Int J Clin Pract 2008, 62:539-554.

20. Robinson JG, Ballantyne CM, Grundy SM, Hsueh WA, Parving HH, Rosen JB, Adewale AJ, Polis AB, Tomassini JE, Tershakovec AM: Lipid-altering efficacy and safety of ezetimibe/simvastatin versus atorvastatin in patients with hypercholesterolemia and the metabolic syndrome (from the VYMET study). Am J Cardiol 2009, 103:1694-1702

21. Rodney RA, Sugimoto D, Wagman B, Zieve F, Kerzner B, Strony J, Yang B, Suresh $R$, Veltri E: Efficacy and safety of coadministration of ezetimibe and simvastatin in African-American patients with primary hypercholesterolemia. J Natl Med Assoc 2006, 98:772-778.

22. Zieve F, Wenger NK, Ben Yehuda O, Constance C, Bird S, Lee R, Hanson ME, Jones-Burton C, Tershakovec AM: Safety and efficacy of ezetimibe added to atorvastatin versus up titration of atorvastatin to $40 \mathrm{mg}$ in Patients > or $=65$ years of age (from the ZETia in the ELDerly [ZETELD] study). Am J Cardiol 2010, 105:656-663.

23. Brohet C, Banai S, Alings AM, Massaad R, Davies MJ, Allen C: LDL-C goal attainment with the addition of ezetimibe to ongoing simvastatin treatment in coronary heart disease patients with hypercholesterolemia. Curr Med Res Opin 2005, 21:571-578.

24. Cruz-Fernandez JM, Bedarida GV, Adgey J, Allen C, Johnson-Levonas AO, Massaad R: Efficacy and safety of ezetimibe co-administered with ongoing atorvastatin therapy in achieving low-density lipoprotein goal in patients with hypercholesterolemia and coronary heart disease. Int $J$ Clin Pract 2005, 59:619-627

25. Feldman T, Koren M, Insull W Jr, McKenney J, Schrott H, Lewin A, Shah S, Sidisin M, Cho M, Kush D, Mitchel Y: Treatment of high-risk patients with ezetimibe plus simvastatin co-administration versus simvastatin alone to attain National Cholesterol Education Program Adult Treatment Panel III low-density lipoprotein cholesterol goals. Am J Cardiol 2004 93:1481-1486

26. Kirilmaz B, Asgun F, Alioglu E, Ercan E, Tengiz I, Turk U, Saygi S, Ozerkan F: High inflammatory activity related to the number of metabolic syndrome components. J Clin Hypertens (Greenwich) 2010, 12:136-144.

27. LaRosa JC, He J, Vupputuri S: Effect of statins on risk of coronary disease: a meta-analysis of randomized controlled trials. JAMA 1999, 282:2340-2346.

28. Grundy SM: Should women be offered cholesterol lowering drugs to prevent cardiovascular disease? Yes. BMJ 2007, 334:982

29. Kendrick M: Should women be offered cholesterol lowering drugs to prevent cardiovascular disease? No. BMJ 2007, 334:983.

30. Baigent C, Blackwell L, Emberson J, Holland LE, Reith C, Bhala N, Peto R, Barnes EH, Keech A, Simes J, Collins R: Efficacy and safety of more intensive lowering of LDL cholesterol: a meta-analysis of data from 170,000 participants in 26 randomised trials. Lancet 2010, 376:1670-1681. 
31. Califf RM, Lokhnygina $Y$, Cannon CP, Stepanavage ME, McCabe $\mathrm{CH}$, Musliner TA, Pasternak RC, Blazing MA, Giugliano RP, Harrington RA, Braunwald E: An update on the IMProved reduction of outcomes: Vytorin Efficacy International Trial (IMPROVE-IT) design. Am Heart J 2010, 159:705-709.

32. Gerdts E, Rossebo AB, Pedersen TR, Boman K, Brudi P, Chambers JB, Egstrup K, Gohlke-Barwolf C, Holme I, Kesaniemi YA, Malbecq W, Nienaber C, Ray S, Skjaerpe T, Wachtell K, Willenheimer R: Impact of baseline severity of aortic valve stenosis on effect of intensive lipid lowering therapy (from the SEAS study). Am J Cardio/ 2010, 106:1634-1639.

33. Rossebo AB, Pedersen TR, Boman K, Brudi P, Chambers JB, Egstrup K, Gerdts E, Gohlke-Barwolf C, Holme I, Kesaniemi YA, Malbecq W, Nienaber CA, Ray S, Skjaerpe T, Wachtell K, Willenheimer R: Intensive lipid lowering with simvastatin and ezetimibe in aortic stenosis. $N$ Engl J Med 2008, 359:1343-1356.

34. SHARP Collaborative Group: Study of Heart and Renal Protection (SHARP): randomized trial to assess the effects of lowering low-density lipoprotein cholesterol among 9,438 patients with chronic kidney disease. Am Heart J 2010, 160:785-794.

35. Merck/Schering-Plough Pharmaceuticals: Vytorin (ezetimibe/simvastatin) [package insert]. USA North Wales, PA, Merck/Schering-Plough Pharmaceuticals; 2009.

36. Bennett $S$, Sager P, Lipka L, Melani L, Suresh R, Veltri E: Consistency in efficacy and safety of ezetimibe coadministered with statins for treatment of hypercholesterolemia in women and men. J Womens Health (Larchmt) 2004, 13:1101-1107.

37. Goldberg AC, Sapre A, Liu J, Capece R, Mitchel YB: Efficacy and safety of ezetimibe coadministered with simvastatin in patients with primary hypercholesterolemia: a randomized, double-blind, placebo-controlled trial. Mayo Clin Proc 2004, 79:620-629.

38. Davidson MH, McGarry T, Bettis R, Melani L, Lipka LJ, LeBeaut AP, Suresh R, Sun S, Veltri EP: Ezetimibe coadministered with simvastatin in patients with primary hypercholesterolemia. J Am Coll Cardiol 2002, 40:2125-2134

39. Ballantyne CM, Blazing MA, King TR, Brady WE, Palmisano J: Efficacy and safety of ezetimibe co-administered with simvastatin compared with atorvastatin in adults with hypercholesterolemia. Am J Cardiol 2004, 93:1487-1494.

40. Stein E, Stender S, Mata P, Sager P, Ponsonnet D, Melani L, Lipka L, Suresh $R$, Maccubbin $D$, Veltri E: Achieving lipoprotein goals in patients at high risk with severe hypercholesterolemia: efficacy and safety of ezetimibe co-administered with atorvastatin. Am Heart J 2004, 148:447-455.

41. Ballantyne CM, Abate N, Yuan Z, King TR, Palmisano J: Dose-comparison study of the combination of ezetimibe and simvastatin (Vytorin) versus atorvastatin in patients with hypercholesterolemia: the Vytorin Versus Atorvastatin (VYVA) study. Am Heart J 2005, 149:464-473.

42. Catapano AL, Davidson MH, Ballantyne CM, Brady WE, Gazzara RA Tomassini JE, Tershakovec AM: Lipid-altering efficacy of the ezetimibe/ simvastatin single tablet versus rosuvastatin in hypercholesterolemic patients. Curr Med Res Opin 2006, 22:2041-2053.

43. Goldberg RB, Guyton JR, Mazzone T, Weinstock RS, Polis A, Edwards P, Tomassini JE, Tershakovec AM: Ezetimibe/simvastatin vs atorvastatin in patients with type 2 diabetes mellitus and hypercholesterolemia: the VYTAL study. Mayo Clin Proc 2006, 81:1579-1588.

44. Kerzner B, Corbelli J, Sharp S, Lipka LJ, Melani L, LeBeaut A, Suresh R, Mukhopadhyay P, Veltri EP: Efficacy and safety of ezetimibe coadministered with lovastatin in primary hypercholesterolemia. Am J Cardiol 2003, 91:418-424.

45. Ballantyne CM, Houri J, Notarbartolo A, Melani L, Lipka LJ, Suresh R, Sun S, LeBeaut AP, Sager PT, Veltri EP: Effect of ezetimibe coadministered with atorvastatin in 628 patients with primary hypercholesterolemia: a prospective, randomized, double-blind trial. Circulation 2003, 107:2409-2415

46. Dobs AS, Guyton JR, McClusky D, Ponsonnet D, Melani L, LeBeaut A Yang B, Veltri E, for the Ezetimibe Study Group: Coadministration of ezetimibe with simvastatin. J Am Coll Cardiol 2003, 41:227A.

47. Farnier M, Volpe M, Massaad R, Davies MJ, Allen C: Effect of coadministering ezetimibe with on-going simvastatin treatment on LDL-C goal attainment in hypercholesterolemic patients with coronary heart disease. Int J Cardiol 2005, 102:327-332.
48. Barrios V, Amabile N, Paganelli F, Chen JW, Allen C, Johnson-Levonas AO, Massaad $R$, Vandormael K: Lipid-altering efficacy of switching from atorvastatin $10 \mathrm{mg} /$ day to ezetimibe/simvastatin 10/20 mg/day compared to doubling the dose of atorvastatin in hypercholesterolaemic patients with atherosclerosis or coronary heart disease. Int J Clin Pract 2005, 59:1377-1386.

49. Constance C, Westphal S, Chung N, Lund M, McCrary SC, JohnsonLevonas AO, Massaad R, Allen C: Efficacy of ezetimibe/simvastatin 10/20 and $10 / 40 \mathrm{mg}$ compared with atorvastatin $20 \mathrm{mg}$ in patients with type 2 diabetes mellitus. Diabetes Obes Metab 2007, 9:575-584.

doi:10.1186/1476-511X-10-146

Cite this article as: Abramson et al:: Response by sex to statin plus ezetimibe or statin monotherapy: A pooled analysis of 22,231 hyperlipidemic patients. Lipids in Health and Disease 2011 10:146.

\section{Submit your next manuscript to BioMed Central and take full advantage of:}

- Convenient online submission

- Thorough peer review

- No space constraints or color figure charges

- Immediate publication on acceptance

- Inclusion in PubMed, CAS, Scopus and Google Scholar

- Research which is freely available for redistribution

Submit your manuscript at www.biomedcentral.com/submit
C) Biomed Central 